\title{
Reduced Aortic Lesions and Elevated High Density Lipoprotein Levels in Transgenic Mice Overexpressing Mouse Apolipoprotein A-IV
}

\author{
Robert D. Cohen, ${ }^{\star}$ Lawrence W. Castellani, ${ }^{\ddagger}$ Jian-Hua Qiao, ${ }^{\ddagger}$ Brian J. Van Lenten, ${ }^{\ddagger}$ Aldons J. Lusis, ${ }^{\ddagger \S}$ and Karen Reue ${ }^{\star \ddagger}$ \\ * Lipid Research Laboratory, West Los Angeles Veterans Affairs Medical Center, Los Angeles, California 90073; ${ }^{\ddagger}$ Department of \\ Medicine, University of California, Los Angeles, California 90095; and ${ }^{\S}$ Department of Microbiology and Molecular Genetics and the \\ Molecular Biology Institute, University of California, Los Angeles, California 90095
}

\begin{abstract}
Transgenic mouse lines carrying several copies of the mouse apo A-IV gene were produced. Lipoprotein composition and function, and aortic lesion development were examined. Apo A-IV levels in the plasma of transgenic mice were elevated threefold compared with nontransgenic littermates on a chow diet, and sixfold in mice fed an atherogenic diet. Plasma concentrations of total cholesterol, HDL cholesterol, triglycerides, and free fatty acids were similar in transgenic and control mice fed a chow diet. However, with the atherogenic diet, male transgenic mice exhibited significantly higher levels of plasma triglycerides $(P<0.05)$, total cholesterol $(P<0.01)$, HDL cholesterol $(P<0.0001)$, and free fatty acids $(P<0.05)$, and lower levels of unesterified cholesterol $(P<0.05)$, than nontransgenic littermates. Expression of the apo A-IV transgene had a protective effect against the formation of diet-induced aortic lesions, with transgenics exhibiting lesion scores of $\sim 30 \%$ those seen in control mice. HDL-sized lipoproteins isolated from transgenic mice fed the atherogenic diet promoted cholesterol efflux from cholesterol-loaded human monocytes more efficiently than comparable lipoproteins from nontransgenic counterparts. Plasma from transgenics also exhibited higher endogenous cholesterol esterification rates. Taken together, these results suggest that apo A-IV levels influence the metabolism and antiatherogenic properties of HDL. (J. Clin. Invest. 1997. 99:1906-1916.) Key words: apo A-IV • atherosclerosis - lipoproteins - cellular cholesterol efflux • transgene
\end{abstract}

\section{Introduction}

The development of atherosclerosis in humans and several experimental animal models has been shown to be inversely correlated to HDL concentration (1). Several recent studies with transgenic mouse models have indicated that the protein composition of HDL also influences the development of aortic lesions (reviewed in references 2-4). For example, transgenic mice with elevated HDL resulting from overexpression of human apo A-I exhibit dramatically reduced fatty streak lesions when maintained on an atherogenic diet (5), whereas mice

Address correspondence to Karen Reue, West Los Angeles Veterans Affairs Medical Center, 11301 Wilshire Blvd., Building 113, Room 312, Los Angeles, CA 90073. Phone: 310-478-3711 ext. 42171; FAX: 310-478-4538; E-mail: Reuek@ucla.edu

Received for publication 21 May 1996 and accepted in revised form 3 February 1997.

The Journal of Clinical Investigation

Volume 99, Number 8, April 1997, 1906-1916 with elevated HDL resulting from overexpression of murine apo A-II develop fatty streak lesions even when maintained on a chow diet (6). Interestingly, mice expressing both human apo A-I and human apo A-II transgenes have similar HDL concentration as apo A-I transgenics, but have 15-fold greater aortic lesion area than the apo A-I transgenics, although lesion area was still reduced to $40 \%$ of that in nontransgenic control mice (7). Together these studies indicate that although elevated HDL levels are protective against aortic lesion development in mice, the levels of apo A-I and apo A-II in HDL significantly affect its role in atherogenesis.

The role of HDL proteins other than apo A-I and apo A-II in determining HDL concentration and influencing the atherogenic process has not been well characterized. Apo A-IV is a good candidate for an additional HDL protein with a potential function in HDL metabolism. Apo A-IV has been demonstrated to be associated with HDL when examined by nondenaturing gradient gel electrophoresis, gel filtration, immunoprecipitation, and immunoaffinity chromatography (8-11), but is easily dissociated from lipoproteins by ultracentifugation (12). Apo A-IV is a $46-\mathrm{kD}$ protein synthesized in intestine and liver and present in plasma, interstitial fluid, and lymph (1316). Postulated functions of apo A-IV include acting as a cofactor for enzymes involved in remodeling HDL and other lipoproteins, serving to stabilize HDL structure, and promoting removal of cellular cholesterol from extrahepatic tissues. In vitro, apo A-IV has been shown to serve as an activator of the enzyme lecithin:cholesterol acyltransferase $(\operatorname{LCAT})^{1}(17,18)$ and to modulate the activation of lipoprotein lipase by apo C-II (19). Additional studies indicate that apo A-IV associates with HDL during the LCAT reaction and causes a depletion of HDL surface lipids, perhaps serving to stabilize the HDL as the LCAT reaction proceeds (20-22). It has also been demonstrated that apo A-IV containing lipoproteins or reconstituted vesicles promote cholesterol efflux from cholesterol loaded fibroblasts (23) and adipose cells (24). In addition, apo A-IV has been implicated in controlling appetite in response to fat in the $\operatorname{diet}(25,26)$. However, most of these activities are not unique to apo A-IV, and the precise physiological role of this protein remains unknown.

A previous report has described the production of transgenic mice expressing high levels of human apo A-IV (27). These mice were prepared on a mixed genetic background and characterized for lipid levels, intestinal lipid absorption, and feeding behavior. Overexpression of human apo A-IV resulted in increased VLDL cholesterol and triglyceride levels and re-

1. Abbreviations used in this paper: FPLC, fast performance liquid chromatography; IDL, intermediate density lipoprotein; IMEM, Iscove's Modified Eagle's Medium; LCAT, lecithin:cholesterol acyltransferase. 
duced HDL cholesterol in chow fed mice. Kinetic studies suggested a delayed clearance of VLDL in the human apo A-IV transgenic animals. The elevated levels of human apo A-IV did not affect intestinal absorption of fat and fat-soluble vitamins, nor did they affect feeding behavior as evaluated by monitoring circadian feeding patterns and food consumption after fasting (27). Susceptibility to fatty streak lesions was not determined in the HuAIVTg mice. Furthermore, a potential complication in the interpretation of the function of apo A-IV in vivo in these mice results from the overexpression of human rather than mouse apo A-IV. It is possible that structural differences between the human and mouse proteins could compromise the interaction of apo A-IV with endogenous mouse proteins involved in lipid metabolism, such as LCAT or other HDL proteins. Thus, to examine the potential involvement of apo A-IV in determining HDL levels and susceptibility to atherosclerosis, we have generated a transgenic mouse model that expresses elevated levels of mouse apo A-IV. Transgenic lines were backcrossed onto the atherosclerosis-susceptible C57BL/ $6 \mathrm{~J}$ strain and characterized for lipid levels, lipoprotein distribution and composition, diet-induced fatty streak lesions, ability of HDL fractions to promote cellular cholesterol efflux, and plasma cholesterol esterification rates.

\section{Methods}

Production of apo A-IV transgenic mice. A mouse genomic apo A-IV clone was isolated from a $\lambda$ FIXII library prepared from NIH3T3 cells (Stratagene Inc., La Jolla, CA) by hybridization to mouse apo A-IV cDNA sequences (28). A 7-kb DNA fragment containing the entire apo A-IV gene and flanking DNA was prepared by digestion with NheI and microinjected into fertilized mouse eggs from C57BL/6J or $(\mathrm{C} 57 \mathrm{BL} / 6 \mathrm{~J} \times \mathrm{DBA} / 2 \mathrm{~J}) \times \mathrm{C} 57 \mathrm{BL} / 6 \mathrm{~J}$ mice. Genomic DNA was isolated from tail biopsies taken from 3-wk-old mice and transgenic founders carrying multiple copies of the apo A-IV gene identified using a PCR assay to detect tandem copies of the apo A-IV transgene (29). Founder mice were back crossed to C57BL/6J for at least three generations before use in these studies to ensure $\sim 93.75 \% \mathrm{C} 57 \mathrm{BL} / 6 \mathrm{~J}$ genetic background. Mice were maintained in a 12-h light-dark cycle and fed mouse chow (Ralston Purina Co., St. Louis, MO) (4\%) or an atherogenic diet consisting of $75 \%$ Purina chow plus $15 \%$ fat (primarily cocoa butter), $1.25 \%$ cholesterol, and $0.5 \%$ sodium cholate (TD90221; Teklad Research Diets, Madison, WI). Mice were fasted $16 \mathrm{~h}$ before blood and tissue collection.

Apo A-IV $m R N A$ analysis. Total RNA was isolated from mouse tissues by extraction with TriZol (Gibco BRL, Gaithersburg, MD). RNA $(10 \mu \mathrm{g})$ was electrophoresed in $1.2 \%$ agarose containing formaldehyde, transferred to nylon membranes (Hybond N+; Amersham Corp., Arlington Heights, IL), and hybridized to ${ }^{32}$ P-labeled cDNA probes for apo A-IV and apo A-I (28). Blots were exposed to phosphor screens, imaged, and quantitated on a Phosphorimager 451 using ImageQuant software (Molecular Dynamics, Sunnyvale, CA).

Apolipoprotein quantitation. Apolipoprotein levels in plasma and fast performance liquid chromatography (FPLC) fractions were determined by SDS-polyacrylamide gel electrophoresis followed by immunoblotting and quantitation with a Phosphorimager. Plasma samples were diluted 1:20 in sample buffer and $10 \mu \mathrm{l}$ of each loaded onto $10 \%$ polyacrylamide gels. Electrophoresis was carried out for $2 \mathrm{~h}$ at $20 \mathrm{~mA}$ and proteins transferred to nitrocellulose $(0.2 \mu \mathrm{m})$ using a Transblot semidry transfer apparatus (Biorad Laboratories, Richmond, CA) at 200 $\mathrm{mA}$ for $0.5 \mathrm{~h}$. Protein bands were detected using polyclonal antibodies followed by detection with iodinated protein A (ICN Biomedicals, Inc., Irvine, CA). Antibodies for apo A-IV, apo A-I, and apo E were described previously $(30,31)$. Filters were exposed to phosphor screens, imaged, and quantitated as described above for RNA analysis.
Plasma lipid measurements. Blood was obtained from mice fasted for $16 \mathrm{~h}$ by retroorbital bleeding under isoflurane anesthesia. Enzymatic assays for total cholesterol, HDL-cholesterol, triglyceride, and free fatty acids were performed in 96-well microtiter plates using a Biomek 2000 Automated Laboratory Workstation (Beckman Instruments, Inc., Fullerton, CA) as described (32). Measurements on plasma samples were performed in triplicate with an external control sample with known analyte concentration included on each plate to ensure accuracy.

Gel filtration chromatography. Plasma lipoproteins were fractionated using an FPLC system with two Superose 6 columns (Pharmacia LKB Biotechnology, Piscataway, NJ) connected in series (33). $400 \mu \mathrm{l}$ aliquots of plasma were applied and $0.5-\mathrm{ml}$ fractions collected at a flow rate of $0.5-\mathrm{ml} / \mathrm{min}$. Cholesterol and triglycerides were measured in each fraction by enzymatic assay as described above.

Quantitation of aortic lesions. 12-wk-old mice were housed individually and fed the atherogenic diet (described above) for 14 wk. Blood was collected immediately before beginning the atherogenic diet, and at 4- and 14-wk points thereafter. After $14 \mathrm{wk}$ on the diet, fasted mice were killed, heart and aorta removed and frozen in OCT embedding compound, and aortic lesions assayed in the aortic sinus (34).

Cholesterol efflux assay. Human monocyte macrophages isolated from healthy donors were cultured for $5 \mathrm{~d}$ in Iscove's Modified Eagle's Medium (IMEM). Cells were then depleted of cellular cholesterol by transferring to medium containing $10 \%$ lipoprotein deficient serum for $16 \mathrm{~h}$. Cellular cholesterol was then radiolabeled by incubation with $\beta$-migrating very low density lipoprotein containing $\left[{ }^{3} \mathrm{H}\right]$ cholesterol (35). After $48 \mathrm{~h}$, the cells were washed three times and incubated $16 \mathrm{~h}$ with $1 \mathrm{mg} / \mathrm{ml}$ HSA in IMEM to allow cholesterol pools to equilibrate. The cells were washed three times and the medium replaced with IMEM containing either $0.1 \%$ BSA (negative control), human HDL (positive control), or mouse HDL FPLC fractions, each at $400 \mu \mathrm{g} / \mathrm{ml}$ protein, for $24 \mathrm{~h}$. FPLC fractionation of mouse plasma was performed as described above, except that column elution buffer did not contain EDTA and sodium azide. Culture medium was then removed, cells washed three times, and lipids extracted from cells in 1.0 $\mathrm{ml}$ of hexane/isopropanol (3:2) for $30 \mathrm{~min}$ at room temperature. Extracts were dried and dissolved in $60 \mu$ isopropanol. Duplicate $20-\mu \mathrm{l}$ aliquots were spotted onto thin layer chromatography plates and developed in hexane/ethyl ether/acetic acid/methanol (85:15:1:1). Regions corresponding to cholesterol and cholesterol esters were scraped and quantitated by liquid scintillation counting. The proportion of radiolabel remaining in cellular lipid after incubation with lipoprotein fractions is a measure of the efficiency of cellular cholesterol efflux.

Monocyte transmigration assay. Cocultures of human aortic endothelial cells and smooth muscle cells were produced by seeding these cells sequentially onto gelatin-coated 96-well microtiter plates so that the entire surface was covered with stratified monolayers of the two cell types, and a substantial amount of extracellular matrix had been produced $(36,37)$. The monocyte transmigration assay was performed as described in Van Lenten et al. (37). In brief, established cocultures were incubated with either no lipoproteins added, human LDL alone $(350 \mu \mathrm{g} / \mathrm{ml})$, or HDL prepared by FPLC from control or transgenic mice $(250 \mu \mathrm{g} / \mathrm{ml})$. After $24 \mathrm{~h}$ the culture supernatants were transferred to untreated cocultures and incubated for $4 \mathrm{~h}$. A $50-\mu \mathrm{l} \mathrm{hu}-$ man monocyte suspension $\left(2.5 \times 10^{5}\right.$ cells $\left./ \mathrm{cm}^{2}\right)$ was added. Cultures were washed, fixed with $1 \%$ glutaraldehyde in PBS, and monocytes enumerated under a magnification of 200.

Serum paraoxonase activity measurements. Paraoxonase activity was determined using paraoxon arylester as the substrate and measuring the increase in the absorbance at $412 \mathrm{~nm}$ due to formation of 4-nitrophenol under conditions previously described (37). Under these conditions, $1 \mathrm{U}$ of activity is defined as $1 \mu \mathrm{mol}$ substrate hydrolyzed per min.

Fractional and molar cholesterol esterification rates in plasma. Cholesterol esterification rates were measured in plasma of control and transgenic mice by determining rate of conversion of [7(n)- 
$\left.{ }^{3} \mathrm{H}\right]$ cholesterol (Amersham Corp.) into cholesterol ester after incubation at $37^{\circ} \mathrm{C}(38)$. The fractional esterification rate was expressed as the percentage of radiolabeled cholesterol after incubation at $37^{\circ} \mathrm{C}$ for 30 min compared with a $0^{\circ} \mathrm{C}$ control incubation. The molar esterification rate was calculated based on the specific activity $(\mathrm{dpm} / \mathrm{nmol}$ free cholesterol) of each sample, after determination of free cholesterol by an enzymatic method (32).

Statistical analysis. The Student's $t$ test of unpaired observations was used to determine significance of differences between control and transgenic mice in lipid and lipoprotein levels, aortic lesions, paraoxonase activity, and monocyte migration. The $t$ test for repeated measures was used to determine significance in cholesterol efflux and food intake studies.

\section{Results}

Production of apo A-IV transgenic mice. A 7-kb mouse genomic DNA fragment containing the apo A-IV gene $(2.6 \mathrm{~kb})$ as well as $2.3 \mathrm{~kb}$ of $5^{\prime}$ flanking DNA and $2.4 \mathrm{~kb}$ of $3^{\prime}$ flanking DNA was injected into fertilized mouse eggs. The transgene fragment contains most of the apo C-III/apo A-IV intergenic region, including sequences corresponding to the intestinal control region that has been identified in the human apo A-I/C-III/A-IV gene complex (39). One transgenic founder was produced on a $(\mathrm{C} 57 \mathrm{BL} / 6 \mathrm{~J} \times \mathrm{C} 3 \mathrm{H}) \mathrm{F}_{1}$ background, and two transgenic founders were produced on a $\mathrm{C} 57 \mathrm{BL} / 6 \mathrm{~J}$ background. Offspring of the founder derived on the mixed genetic background (transgenic line 1) were subsequently backcrossed to C57BL/6J for at least three generations to produce mice with $>93 \%$ C57BL/6J genomic DNA sequences for use in the studies described below. Offspring of one of the C57BL/6J founders (transgenic line 2) showed 100\% concordance between transmission of the transgene and male sex, indicating that the transgene had integrated into the $\mathrm{Y}$ chromosome. The third founder and his offspring bred infrequently and produced very small litters. Initial characterization of apo A-IV expression in these mice showed only mild elevation, suggesting that the reduced reproduction in these mice was not due to transgene expression, but perhaps to some other effect of the transgene DNA, such as the genomic integration site. Due to difficulties in breeding line 3 mice, studies reported here were performed only with transgenic lines 1 and 2 . Transgenic lines 1 and 2 had normal body weight and exhibited no evidence that chronic overexpression of apo A-IV affects food consumption (data not shown).

Apo A-IV transgene expression levels. Transgene expression levels and tissue distribution were evaluated by comparing apo A-IV mRNA levels in tissues of transgenic and nontransgenic mice by Northern blot followed by phosphorimaging. As shown in Fig. $1 a$, apo A-IV mRNA levels in line 1 transgenic mice were elevated three- to fivefold in intestine, but were not elevated in liver; apo A-I mRNA levels did not differ between transgenics and controls in either tissue. Trace amounts of apo A-IV mRNA were apparent in stomach of both transgenic and nontransgenic mice, and undetectable in other tissues surveyed (kidney, spleen, pancreas, heart, skeletal muscle, brain, white adipose, testis, adrenal, thymus, and thyroid; data not shown). These results indicate that the apo A-IV transgene contains DNA regulatory sequences sufficient to direct expression in intestine, but not in liver. Feeding an atherogenic diet containing $15 \%$ fat, $1.25 \%$ cholesterol, and $0.5 \%$ cholic acid resulted in threefold elevations in intestinal apo A-IV mRNA over basal levels in both transgenics and nontransgenics (Fig.

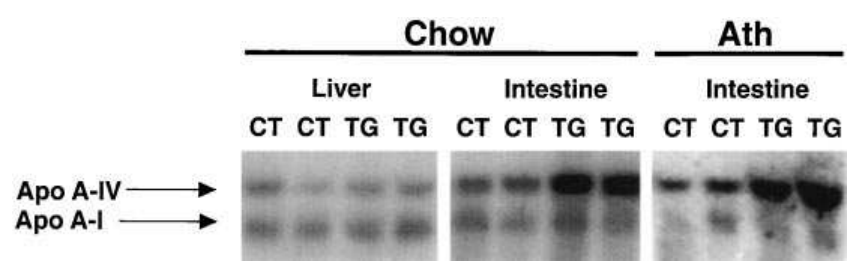

Figure 1. Apo A-IV and apo A-I mRNA levels in liver and intestine of control and transgenic mice. Total RNA was prepared from liver and intestine of control $(C T)$ and transgenic $(T G)$ mice fed the chow and atherogenic (Ath) diets. RNA $(10 \mu \mathrm{g})$ was blotted to nylon membrane and hybridized to probes for mouse apo A-IV and apo A-I. Hybridization signals were detected by phosphorimaging and quantitated using ImageQuant software.

1, right). Thus, the transgene also may contain endogenous apo A-IV gene regulatory signals that are responsive to dietary fat or some other component of the atherogenic diet.

The relative levels of mouse apo A-IV protein in the plasma of transgenic and nontransgenic littermates were examined by Western blot analysis and quantitated by phosphorimaging. Chow-fed line 1 transgenic mice had plasma apo A-IV levels approximately threefold higher than control mice on the chow diet and sixfold higher after feeding on the atherogenic diet for $5 \mathrm{~d}$ (Fig. 2). Line 2 transgenics exhibited plasma apo A-IV protein levels that are 1.5-2-fold higher than age matched male C57BL/6J mice (not shown). Intestinal ring labeling studies performed with nonfasted, chow-fed line 1 mice demonstrated that apo A-IV protein synthesis is increased two- to threefold in small intestine from transgenic mice (data not shown). The relative levels of apo A-I and apo $\mathrm{E}$ were also quantitated on Western blots containing plasma

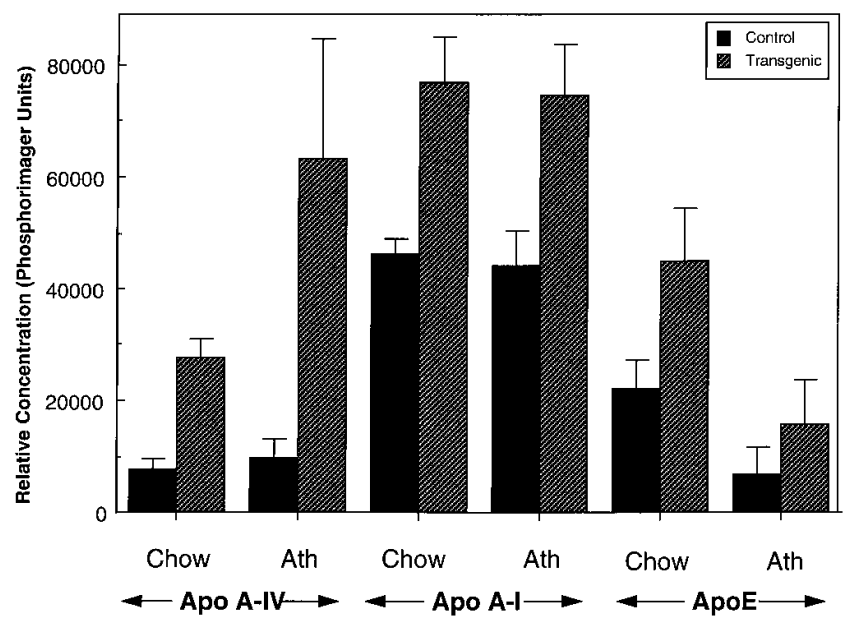

Figure 2. Apo A-IV, apo E, and apo A-I levels in plasma from control and transgenic mice. Fasting plasma samples from control and transgenic mice fed the chow and atherogenic (Ath) diets were analyzed by Western blotting. Protein bands binding apolipoproteinspecific antibodies were detected with iodinated ${ }^{125}$ I protein A followed by phosphorimaging. Quantitation of relative apolipoprotein levels was performed with ImageQuant software. Relative protein levels are expressed as Phosphorimager units and represent the mean of five animals of each type on each diet; error bars represent standard error. 
Table I. Fasting Plasma Lipid Levels in apo A-IV Transgenic and Control Mice

\begin{tabular}{|c|c|c|c|c|c|c|c|c|c|c|c|}
\hline & \multicolumn{3}{|c|}{ Triglycerides } & \multicolumn{3}{|c|}{ Total cholesterol } & \multicolumn{3}{|c|}{ HDL cholesterol } & \multicolumn{2}{|c|}{ Free fatty acids } \\
\hline & Chow & $4 \mathrm{wk}$ Ath & $14 \mathrm{wk}$ Ath & Chow & $4 \mathrm{wk}$ Ath & $14 \mathrm{wk}$ Ath & Chow & $4 \mathrm{wk}$ Ath & $14 \mathrm{wk}$ Ath & Chow & $14 \mathrm{wk}$ Ath \\
\hline \multicolumn{12}{|l|}{ Line 1} \\
\hline \multicolumn{12}{|l|}{ Female } \\
\hline Control & $81.2 \pm 41.7$ & $4.1 \pm 2.9$ & $2.2 \pm 1.3$ & $95.5 \pm 26.8$ & $162.9 \pm 42.3$ & $111.7 \pm 31.9$ & $81.3 \pm 6.0$ & $15.3 \pm 4.5$ & $42.3 \pm 17.9$ & $74.4 \pm 27.4$ & $28.6 \pm 6.0$ \\
\hline A-IV Tg & $78.0 \pm 13.0$ & $5.0 \pm 1.0$ & $4.8 \pm 3.1$ & $93.7 \pm 29.8$ & $172.9 \pm 33.6$ & $132.1 \pm 33.4$ & $76.5 \pm 23.7$ & $34.5 \pm 13.4 *$ & $50.4 \pm 19.1$ & $97.7 \pm 15.9$ & $29.8 \pm 10.9$ \\
\hline \multicolumn{12}{|l|}{ Male } \\
\hline Control & $86.7 \pm 44.8$ & $5.9 \pm 2.5$ & $6.0 \pm 3.2$ & $114.3 \pm 25.5$ & $166.6 \pm 62.5$ & $121.1 \pm 36.1$ & $92.7 \pm 19.2$ & $56.6 \pm 14.7$ & $42.7 \pm 12.4$ & $77.9 \pm 3.9$ & $25.6 \pm 5.0$ \\
\hline A-IV Tg & $96.1 \pm 39.1$ & $7.9 \pm 8.9$ & $18.4 \pm 12.6^{*}$ & $118.1 \pm 26.8$ & $217.8 \pm 76.4$ & $200.9 \pm 40.9^{\dagger}$ & $91.1 \pm 32.1$ & $118.1 \pm 7.9^{\S}$ & $93.2 \pm 17.8^{\S}$ & $94.1 \pm 22.4$ & $34.0 \pm 7.2^{*}$ \\
\hline \multicolumn{12}{|l|}{ Line 2} \\
\hline \multicolumn{12}{|l|}{ Male } \\
\hline Control & ND & ND & ND & $72.9 \pm 16.9$ & $179.7 \pm 49.9$ & $124.8 \pm 16.1$ & $62.2 \pm 12.0$ & $54.8 \pm 21.7$ & $61.3 \pm 3.2$ & ND & $30.6 \pm 1.6$ \\
\hline A-IV Tg & ND & ND & ND & $112.8 \pm 19.4^{\dagger}$ & $212.3 \pm 50.3^{\dagger}$ & $185.6 \pm 11.1^{\dagger}$ & $91.3 \pm 18.9 *$ & $73.1 \pm 11.4$ & $111.2 \pm 16.3$ & ND & $34.4 \pm 2.5$ \\
\hline
\end{tabular}

All values are expressed as $\mathrm{mg} / \mathrm{dl}$ and represent the mean $\pm \mathrm{SD}$ of determinations from 5 to 12 individual mice. Mice were fed the chow or atherogenic $\operatorname{diet}(A t h)$ for 4 or $14 \mathrm{wk}$. All mice were fasted $12 \mathrm{~h}$ before blood collection. Controls for Line 1 transgenic mice are age- and sex-matched nontransgenic littermates. Controls for Line 2 transgenic mice are age-matched male C57BL/6J mice. $A-I V T g$, apo A-IV transgenic; $N D$, not determined. *Significantly different from nontransgenic counterparts at $P<0.05$. 'Significantly different from nontransgenic counterparts at $P<0.01$. ${ }^{8}$ Significantly different from nontransgenic counterparts at $P<0.001$.

from transgenic and control mice. Apo A-I levels were increased $\sim 40 \%$ and apo E levels were increased twofold in transgenic compared with control mice on both chow and atherogenic diets (Fig. 2).

Plasma lipids and lipoprotein levels in apo A-IV transgenic mice. Plasma lipid levels were determined in transgenic mice from lines 1 and 2 on the chow diet and on the atherogenic diet for 4 and $14 \mathrm{wk}$, and are summarized in Table I. In line 1 transgenic mice, apo A-IV overexpression did not significantly affect fasting levels of triglyceride, total cholesterol, HDL cholesterol, or free fatty acids in mice fed a chow diet. When mice were fed the atherogenic diet for 4 or $14 \mathrm{wk}$, triglyceride levels dropped to $\sim 5 \%$ of the levels in chow fed mice in both controls and transgenics but were significantly higher in male transgenics compared with male controls at $14 \mathrm{wk}$ on the atherogenic diet $(P<0.05)$. Similarly, free fatty acid levels decreased in all mice as a consequence of eating the atherogenic diet, but levels remained significantly higher in male transgenics compared to controls $(P<0.05)$. Line 1 male transgenics had $60 \%$ higher total cholesterol levels $(P<0.01)$ than controls at $14 \mathrm{wk}$ on the diet. More striking was the twofold elevation in HDL cholesterol levels in both male $(P<0.001)$ and female $(P<0.05)$ transgenics after 4 wk on the atherogenic diet, and in male transgenics $(P<0.001)$ after $14 \mathrm{wk}$.

The effects of apo A-IV overexpression on total and HDL cholesterol levels were also observed in the line 2 transgenic mice. As described above, this line was derived on a pure C57BL/6J background with transgene transmission to all males and no females; thus, age-matched $\mathrm{C} 57 \mathrm{BL} / 6 \mathrm{~J}$ male mice were used as controls. As with line 1 mice, line 2 transgenics exhibited significantly elevated total and HDL cholesterol levels (Table I, bottom). Interestingly, chow-fed line 2 mice exhibited $50 \%$ elevations in both total cholesterol $(P<0.01)$ and HDL cholesterol $(P<0.05)$; on the atherogenic diet, total cholesterol was elevated $50 \%$ after $4 \mathrm{wk}(P<0.01)$ and HDL cholesterol was elevated $30 \%$ after $14 \mathrm{wk}(P<0.05)$. Thus, in the two independent transgenic lines, an increase in plasma apo
A-IV concentration was associated with increased total and HDL cholesterol levels on a chow diet (line 2) and the atherogenic diet (lines 1 and 2). The effect was most pronounced in male mice of line 1, but was also significant in HDL levels of female line 1 transgenics fed the atherogenic diet for $4 \mathrm{wk}$. Line 1 mice were therefore used for subsequent lipoprotein characterizations.

The distribution of lipids and proteins among lipoprotein classes was examined by fractionating plasma via FPLC on two Superose columns connected in series (33). The distribution of cholesterol among fractions was similar in chow-fed line 1 transgenic and control mice, with the majority of cholesterol present in fractions in the size range corresponding to HDL as is typical for mice (Fig. $3 a$ ). After feeding the atherogenic diet for $2 \mathrm{wk}$, however, the cholesterol profiles were strikingly different between transgenic and control mice. Control mice exhibited a reduction in HDL cholesterol, whereas transgenic mice had increased HDL cholesterol levels compared with their chow-fed counterparts (Fig. $3 b$ ). Both control and transgenic mice displayed increased cholesterol in lipoproteins in the IDL/LDL and VLDL size ranges in response to the atherogenic diet; these effects were most pronounced in control mice (Fig. $3 b$ ). In addition to lower LDL/VLDL cholesterol levels, transgenic mice exhibited substantially lower levels of unesterified cholesterol in those fractions (Fig. $3 c$ ). Interestingly, the proportion of cholesterol present in whole plasma in the unesterified form (unesterified cholesterol/total cholesterol) was similar between controls and transgenics fed the chow diet $(0.41 \pm 0.06$, control vs $0.42 \pm 0.07$, transgenic), but substantially lower in transgenics fed the atherogenic diet (0.68 \pm 0.10 , control vs $0.38 \pm 0.10$, transgenic; $P<0.05)$. Thus, the distribution of cholesterol among the lipoproteins, as well as the extent of esterification, is clearly altered in transgenic compared with control mice fed the atherogenic diet.

Apolipoprotein levels and distribution in apo A-IV transgenic mice. An examination of the apolipoprotein distribution among FPLC fractions by quantitative Western blotting also 

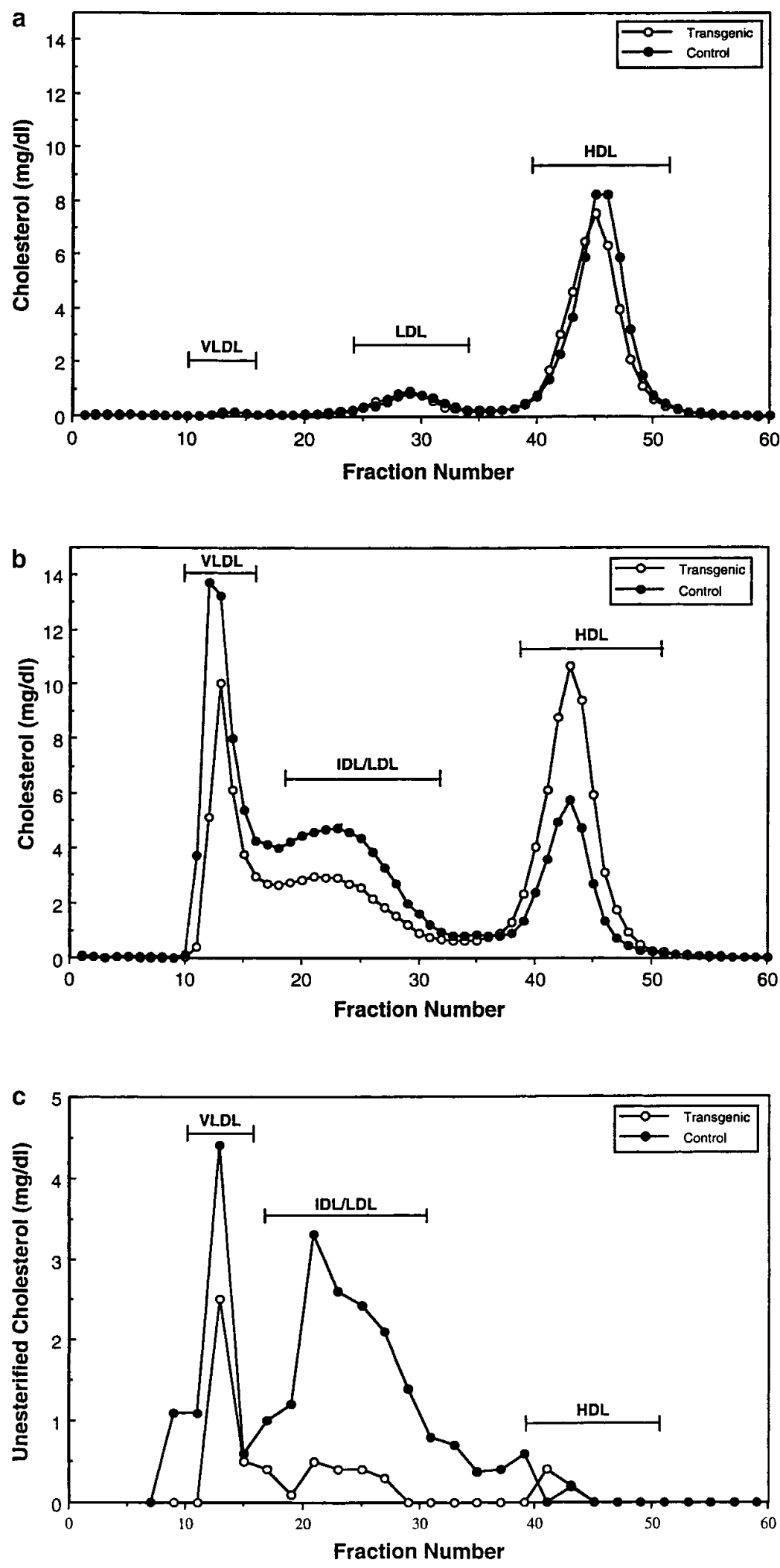

Figure 3. Cholesterol distribution in plasma lipoproteins from control and transgenic mice. Fasting plasma lipoproteins from pooled plasma of four male mice/group were fractionated by FPLC (see Methods). For each separation, $400 \mu \mathrm{l}$ of plasma was applied to the column. Fractions $(0.5 \mathrm{ml})$ were collected and cholesterol quantitated in duplicate by enzymatic assay. The positions at which VLDL, IDL, LDL, and HDL that have been isolated by density ultracentrifugation elute from the column are indicated. Total cholesterol profiles for control and transgenic mice maintained on the chow diet and atherogenic diet for $2 \mathrm{wk}$ are shown in $a$ and $b$, respectively. Panel $c$ shows the levels and distribution of unesterified cholesterol from control and transgenic mice fed the atherogenic diet. Profiles shown are representative of experiments repeated with three independent groups of mice. revealed important differences between transgenic and control mice. In chow-fed control and transgenic mice, apo A-IV occurs in three distinct populations (Fig. 4): a small amount elutes in fractions corresponding in size to LDL (peak 1), a more abundant species co-elutes with HDL (peak 2), and a third population elutes in a lipid-poor plasma fraction (peak 3). The occurrence of apo A-IV in a lipid-poor state is characteristic for this apolipoprotein in the plasma of humans, rats, mice, and other species (8-14). This relatively weak association of apo A-IV with lipoproteins may be attributable to the 

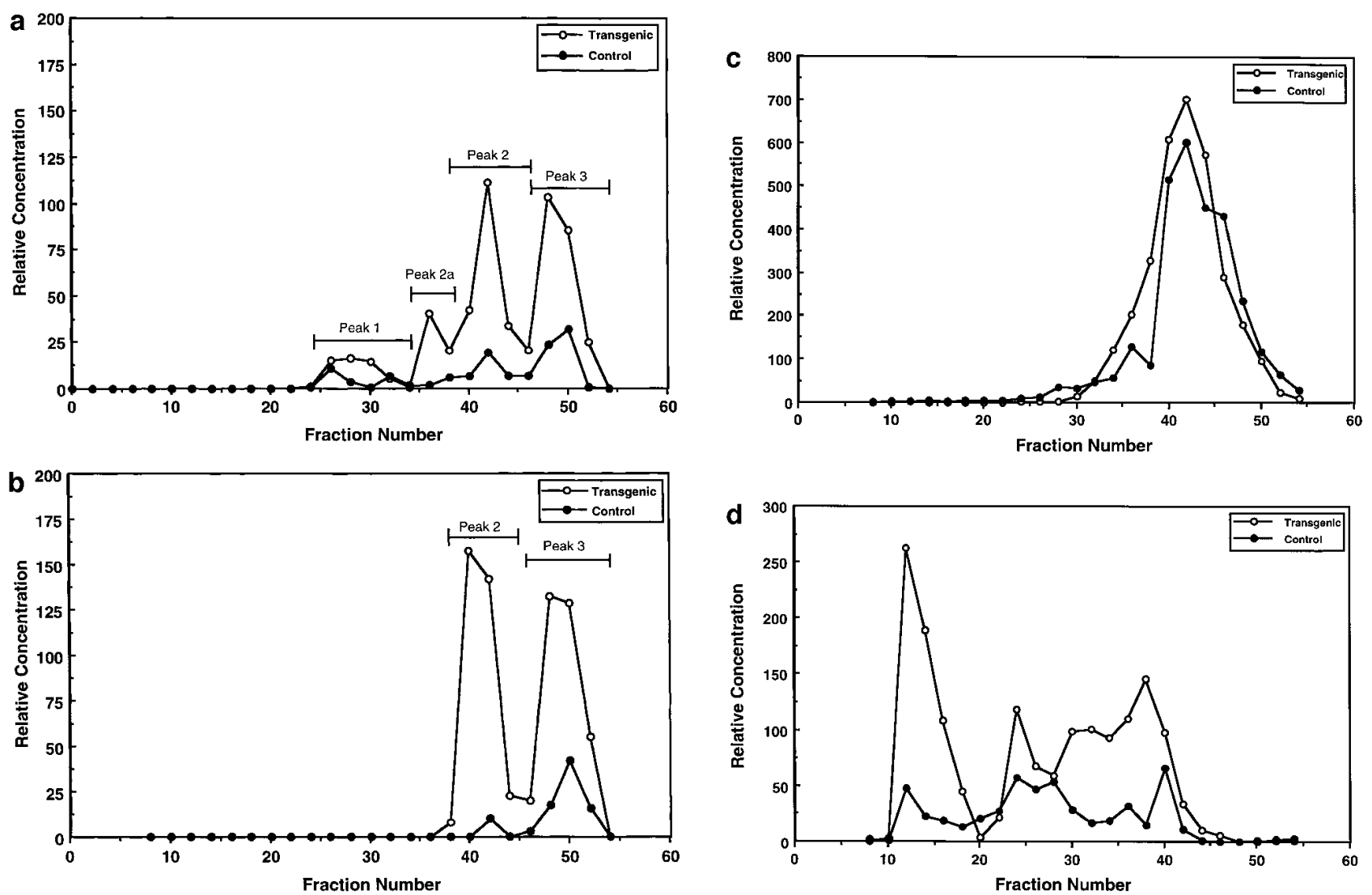

Figure 4. Apolipoprotein distribution in plasma lipoproteins from control and transgenic mice. Fasting plasma lipoproteins from pooled plasma of four male mice/group were fractionated by FPLC. Fractions $(0.5 \mathrm{ml})$ were collected and analyzed for apolipoprotein content by Western blotting as detailed in Methods. Relative apolipoprotein levels were determined by phosphorimaging and quantitation using ImageQuant software. Relative levels of apo A-IV in control and transgenic mice fed a chow diet $(a)$, and of apo A-IV $(b)$, apo A-I $(c)$, and apo E $(d)$ in mice fed the atherogenic diet for $4 \mathrm{wk}$ are shown. Note that the ordinate scales differ between panels.

high hydrophilicity of apo A-IV compared with other apolipoproteins. Transgenics, but not control mice, exhibit an additional distinct population of apo A-IV-containing lipoproteins with a size intermediate between LDL and HDL (peak $2 a$, fractions 34-38). The relative amount of apo A-IV in each of the lipoprotein species is elevated in transgenic mice, with a $50 \%$ increase in peak 1 , an eightfold increase in peak 2 , and a 4.5-fold increase in peak 3 . In mice fed the atherogenic diet for $4 \mathrm{wk}$, the apo A-IV is no longer detectable in the LDL size range (peak 1 above) or in peak $2 a$, but is increased in both peaks 2 and 3, with transgenics exhibiting eightfold and fivefold higher levels than controls in the two species, respectively (Fig. $4 b$ ).

As shown in Fig. 2, apo A-IV transgenic mice have elevated plasma levels of apo A-I and apo E as well. We examined the distribution of these apolipoproteins among FPLC fractions. Apo A-I was restricted to HDL fractions in both control and transgenic mice on both diets, with $20-40 \%$ higher levels in transgenic mice compared to control mice fed the atherogenic diet (Fig. $4 c$ ). On the chow diet, apo E occurred at similar concentrations in control and transgenic mice, and was distributed primarily in the LDL size range (fractions 24-34), with small amounts in the HDL range (fractions 38-52) (not shown). In mice fed the atherogenic diet, apo E was widely distributed in fractions corresponding to VLDL, LDL, and HDL, and apo E concentration was elevated more than twofold in transgenics, particularly in VLDL, LDL, and large HDL fractions (Fig. $4 d$ ). Overall, it appears that apo A-IV transgenic mice fed the atherogenic diet exhibit elevated apo A-IV/apo A-I ratios in HDL, and increased levels of apo E distributed throughout all lipoprotein classes.

Diet-induced aortic lesions are reduced in apo A-IV transgenic mice. We evaluated the effect of increased plasma apo A-IV levels on aortic lesion formation in mice fed the atherogenic diet for $14 \mathrm{wk}$ as described (34). In a study of 19 transgenic and 18 control littermates, lesion scores in transgenics were reduced to $\sim 30 \%$ of those in control mice (Table II). The difference in lesion scores between male transgenic and control mice was highly significant $(P<0.006$, Mann-Whitney $\mathrm{U}$ test). As in previous studies with $\mathrm{C} 57 \mathrm{BL} / 6 \mathrm{~J}$ mice, females (both controls and transgenics) had significantly higher lesion scores than males (Table II; reference 34). As with the male transgenic mice, average lesion scores in female transgenics were reduced to one-third of those in controls, although mouse-to-mouse variation in lesion scores was greater in females than in males. Thus, elevated expression of apo A-IV is associated with a substantial reduction in fatty streak lesions in the aortic sinus.

$H D L$-sized lipoproteins from apo A-IV transgenics promote cellular cholesterol efflux and inhibit LDL oxidation. It has been proposed that apo A-IV may play a role in reverse cholesterol transport based, in part, on observations that re- 
Table II. Aortic Lesions in apo A-IV Transgenic and Control Mice

\begin{tabular}{|c|c|c|c|c|}
\hline & \multicolumn{3}{|c|}{ Mean lesion area $\left(\mu \mathrm{m}^{2} \pm \mathrm{SE}[n]\right)$} & \multirow[b]{2}{*}{$P$ value } \\
\hline & Control & Transgenic & Transgenic/control & \\
\hline Male & $1346 \pm 276(11)$ & $439 \pm 154(11)$ & 0.33 & 0.006 \\
\hline Female & $18923 \pm 10100(8)$ & $6746 \pm 1553(7)$ & 0.36 & NS \\
\hline
\end{tabular}

Male and female control and apo A-IV transgenic mice were fed the atherogenic diet for $14 \mathrm{wk}$ and aortic lesions were evaluated. Lesion scores are presented as mean lesion area in $\mu \mathrm{m}^{2} \pm \mathrm{SE}$. Numbers in parentheses indicate the number of mice analyzed. Values for control and transgenic mice were compared using the Mann-Whitney U test.

constituted lipid vesicles containing apo A-IV promote cholesterol efflux from cultured fibroblasts and adipocytes $(23,24)$. We investigated whether the increased concentration of apo A-IV in HDL of transgenic mice leads to enhanced cellular cholesterol efflux. HDL-sized lipoproteins were isolated by FPLC rather than ultracentrifugation because apo A-IV becomes dissociated from HDL when prepared with the latter technique (12). FPLC fractions corresponding to apo A-IVcontaining HDL (fractions 38-54) were pooled and total protein concentrations determined; equal aliquots of protein from control and transgenic mice, as well as from a human HDL control sample, were used in the cholesterol efflux assay.

Cultured primary macrophages were loaded with radiolabeled cholesterol for $48 \mathrm{~h}$ and then incubated for $24 \mathrm{~h}$ with apo A-IV-containing lipoproteins prepared as described above from transgenic and control mice fed the atherogenic diet for 1 wk. As shown in Fig. 5, the amount of labeled cholesterol remaining in the cells after incubation with human HDL is reduced $\sim 50 \%$ compared with incubation with $0.1 \%$ BSA. Incubation with HDL-sized lipoproteins from female and male control mice reduced cellular cholesterol content by 52 and $43 \%$, respectively. Lipoproteins from transgenic mice reduced cholesterol content further, by $67 \%$ for females and $66 \%$ for males; this represents a significant difference between HDL from control and transgenic mice $(P<0.05$ for both males and females). Identical results were obtained in two completely independent experiments performed with pooled plasma samples from different mice and independent monocyte/macrophage preparations from different human donors. These data indicate that the altered protein composition of HDL from apo A-IV transgenics confers a greater capacity for promoting cellular cholesterol efflux.

In addition to its proposed function in cholesterol efflux, the antiatherogenic properties of HDL have been attributed to an ability to protect against oxidative modification of LDL and the resultant inflammatory processes that attract macrophages to the artery wall (reviewed in reference 40). To compare the protective properties of HDL from transgenic and control mice, we utilized a monocyte migration assay. This assay uses a coculture model of the artery wall consisting of a monolayer of endothelial cells in association with smooth muscle cells and an extracellular matrix elaborated by the cells in culture (36). The coculture provides a microenvironment in which exogenously added LDL becomes oxidized; the oxidized LDL subsequently induces monocytes to migrate through a membrane into the coculture. The number of transmigrating monocytes directly

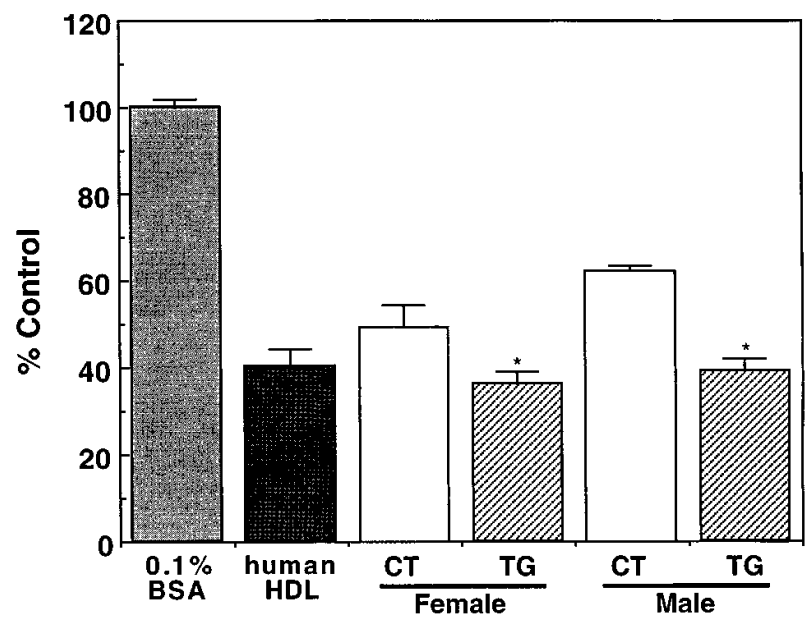

Figure 5. Stimulation of cholesterol efflux from cholesterol-loaded human macrophages by HDL fractions from control and transgenic mice. Male and female control and transgenic mice were maintained on the atherogenic diet for $2 \mathrm{wk}$ and fasted $16 \mathrm{~h}$. Plasma was obtained from four mice of each group, pooled, and lipoproteins fractionated by FPLC. Cholesterol levels were determined in all fractions to locate HDL-sized lipoproteins for use in the assay. Human macrophages which had been loaded with radiolabeled cholesterol were incubated with either delipidated $0.1 \%$ BSA, $400 \mu \mathrm{g}$ human HDL protein, or $400 \mu \mathrm{g}$ HDL protein from control $(C T)$ or transgenic $(T G)$ mice. The amount of radioactivity remaining in the macrophages after a $24-\mathrm{h}$ incubation was determined. Results are expressed as the percentage of initial radioactivity present in cells. Values shown are mean \pm SD of eight replicates. Asterisks above bars for female and male transgenic values indicate a significant difference from corresponding controls $(P<0.05)$. Identical results were obtained in independent experiments performed with plasma fractions obtained from two different sets of mice.

reflects the degree to which the LDL was oxidized and can be used to assess the ability of exogenously added HDL to prevent LDL oxidation.

Fig. 6 shows the relative levels of monocyte transmigration when cocultures were incubated without exogenous LDL, with LDL alone, or LDL in combination with control or transgenic HDL prepared as described in the preceding section. Without exogenous LDL, a baseline of eight monocytes/high power field were detected, whereas the addition of LDL produced nearly a fivefold increase in monocyte transmigration. The addition of LDL together with HDL-sized lipoproteins from both male and female control mice reduced the monocyte migration by $\sim 50 \%$. HDL from male transgenics had an even more pronounced effect, with migration reduced to $23 \%$ of that seen for LDL alone $(P<0.05)$; HDL from female transgenics also reduced monocyte migration further than HDL from control mice (down to $37 \%$ of the LDL control). These results indicate that HDL from apo A-IV transgenic mice reduce LDL oxidation as assessed by monocyte migration in the coculture system.

The antioxidant properties of HDL have been ascribed, in part, to HDL-associated serum paraoxonase activity $(41,42)$. To test whether the enhanced antioxidation activity of transgenic HDL is correlated with increased paraoxonase levels, we determined activity of this enzyme in HDL fractions from control and transgenic mice. As shown in Fig. 7, HDL fractions 


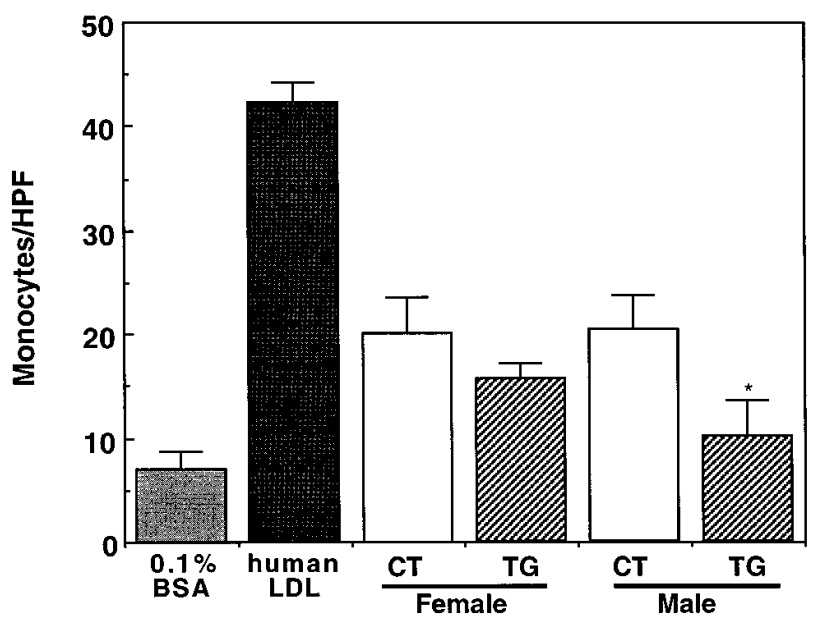

Figure 6. Effect of transgenic and control HDL fractions on monocyte transmigration in a coculture assay. Cocultures of human aortic endothelial and smooth muscle cells were treated with freshly isolated human LDL. To some wells, the LDL was added after the addition for $24 \mathrm{~h}$ of HDL $(400 \mu \mathrm{g} / \mathrm{ml})$ from control or transgenic mice prepared as described in Fig. 5 legend. The resulting conditioned medium was transferred to target cocultures for $24 \mathrm{~h}$, after which a suspension of Dil-labeled monocytes was added to the endothelial side of the culture. After a 60-min incubation, the medium was removed, cells washed and fixed, and the number of subendothelial monocytes counted under magnification of 625 . Values shown are mean \pm SD of the number of monocytes in 25 high-power fields $(H P F)$ in four cocultures for each treatment. The asterisk above the bar for male transgenics indicates a significant difference from corresponding controls $(P<0.05)$.

from male and female control mice were similar, whereas activity in transgenics was increased by $36 \%$ in females and $70 \%$ in males $(P<0.05)$. Thus, increased paraoxonase activity may serve to prevent lipid oxidation and contribute to the apparent antiatherogenic property of HDL from apo A-IV transgenic mice.

Cholesterol esterification is increased in plasma from apo $A-I V$ transgenic mice. HDL-mediated cholesterol efflux from cells is known to be accelerated with increased rates of cholesterol esterification by LCAT (43). It has also been shown that apo A-IV present on artificial phospholipid/cholesterol substrates can activate LCAT in vitro (17). To determine whether increased levels of apo A-IV in plasma would result in increased cholesterol esterification rates, we quantitated cholesterol esterification in plasma from transgenic and control mice by incubation of plasma with radiolabeled cholesterol followed by quantitation of label incorporated into cholesterol ester (38). As shown in Table III, the fractional esterification rate and molar esterification rate were two- to threefold higher in transgenic compared to control mice $(P<0.05)$. We propose that increased esterification of free cholesterol in plasma of transgenic mice may be one mechanism contributing to the lower proportion of unesterified cholesterol (see Fig. $3 c$ ) and increased cholesterol efflux observed for HDL from these animals.

\section{Discussion}

We have produced and characterized transgenic mice carrying multiple copies of the mouse apo A-IV gene and examined the
Table III. Endogenous Cholesterol Esterification Rate in Plasma of apo A-IV Transgenic and Control Mice

\begin{tabular}{lcc}
\hline \multicolumn{1}{c}{ Strain } & FER plasma $(\% / \mathrm{h})$ & MER plasma $(\mu \mathrm{mol} / \mathrm{h} / \mathrm{l})$ \\
\hline Control & $2.2 \pm 0.54$ & $12.5 \pm 2.6$ \\
Apo A-IV Tg & $5.5 \pm 0.86$ & $36.3 \pm 6.8$ \\
& $P<0.05$ & $P<0.05$
\end{tabular}

Determinations were performed with plasma samples from four to six control and transgenic mice fed the atherogenic diet for $2 \mathrm{wk}$. All values represent mean \pm SE. $F E R$, fractional esterification rate expressed as percentage of ${ }^{3} \mathrm{H}$-cholesterol esterified in a 30 -min incubation. MER, molar esterification rate based on the specific activity $(\mathrm{dpm} / \mathrm{nmol}$ free cholesterol) of each sample.

consequences of increased apo A-IV expression on lipoprotein concentrations, development of diet-induced aortic lesions, cellular cholesterol efflux, and cholesterol esterification rates in plasma. The most striking features of the apo A-IV transgenic phenotype are reduced susceptibility to aortic lesion formation and the occurrence of up to twofold higher HDL levels than control mice when fed an atherogenic diet. In addition, HDL fractions from transgenics tested in vitro exhibit antiatherogenic properties including increased capacity to promote cellular cholesterol efflux, protection of LDL from oxidative modification, and increased activity of the antioxidant paraoxonase.

We chose to use a transgene from mouse rather than a heterologous species to ensure that interactions between apo A-IV and endogenous mouse proteins involved in lipid metabolism, that is, LCAT, other HDL proteins, cell surface receptors, would not be compromised by species differences in apo A-IV structure. Precedence exists for different phenotypes resulting from transgenic expression of mouse vs human pro-

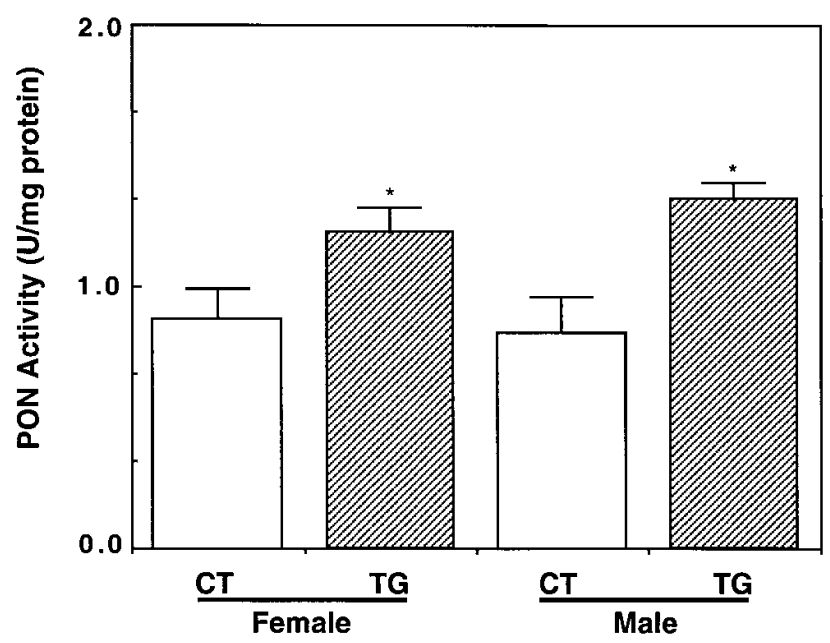

Figure 7. Paraoxonase (PON) activity in HDL fractions from control and transgenic mice. Paraoxonase activity was determined in HDLsized lipoproteins isolated from pooled plasma samples from control and transgenic mice as described in Fig. 5 legend. Data are expressed as units of activity against an arylester substrate/mg HDL protein. Values shown are mean \pm SD for eight determinations. Asterisks above bars for female and male transgenic values indicate a significant difference from corresponding controls $(P<0.05)$. 
teins, as in the case of apo A-II. Transgenic mice expressing human apo A-II were found to have a mild phenotype with normal HDL cholesterol levels, but with an additional population of small HDL containing almost exclusively human apo A-II (44). In contrast, mice overexpressing mouse apo A-II had twofold elevations in HDL cholesterol, and the male transgenics exhibited increased susceptibility to fatty streak lesions on both chow and atherogenic diets $(6,32)$. These differences may be related to structural differences between human and mouse apo A-II that influence interactions with other proteins in a species-specific manner.

A comparison of the phenotype of mouse apo A-IV transgenics described here and previously reported human apo A-IV transgenics revealed both similarities and significant differences. In both cases, transgene expression occurred primarily in intestine, suggesting that tissue-specific DNA regulatory sequences flanking the mouse and human apo A-IV genes may be conserved. An enhancer localized to the region between the divergently transcribed human apo C-III and apo A-IV genes has been shown to direct the expression of apo A-I in intestinal epithelium $(39,45)$. It is possible that this same regulatory region, which appears to be present in both the mouse and human apo A-IV transgene constructs, determines intestinal expression of apo A-IV as well as the apo A-I and apo C-III genes.

Apo A-IV protein was distributed approximately equally between HDL and lipid-poor fractions of plasma in chow-fed mice carrying both mouse and human apo A-IV transgenes. However, the circulating levels of apo A-IV protein in the mouse apo A-IV transgenic were elevated threefold, compared with 6- and 25-fold elevations in the human apo A-IV transgenic mice (low- and high-expressing strains, respectively) (27). In both transgenics, the levels of apo A-IV mRNA and protein increased in mice fed a high fat diet, even though the diet composition was different (mouse apo A-IV transgenic mice were fed an atherogenic diet containing $15 \%$ fat, $1.25 \%$ cholesterol, $0.5 \%$ cholic acid; human apo A-IV transgenics were fed an adjusted calories Western-type diet containing $21 \%$ fat, $0.15 \%$ cholesterol). It was necessary to use the atherogenic diet in the current studies of the mouse apo A-IV transgenic to assess the effect of apo A-IV level on atherogenesis (see below).

In mice fed a chow diet, the fasting concentrations of cholesterol and triglyceride were similar in transgenics and controls, but transgene expression had significant effects on lipid levels in mice fed a high fat diet. Since different high fat diets were used in the studies of mouse and human apo A-IV transgenics, it is difficult to make direct comparisons regarding the relative effects of mouse versus human transgene expression on lipoprotein levels. Nevertheless, it is interesting to note that the mouse apo A-IV transgenics maintained higher HDL levels compared with controls, whereas the high-expressing human apo A-IV transgenics had increased VLDL and diminished HDL (Table I and reference 27). As has been described in several earlier studies, the atherogenic diet typically increases total cholesterol levels but reduces HDL cholesterol levels by approximately one-half in C57BL/6J mice $(6,31,34$, 46). Mouse apo A-IV transgenics differed from control mice in exhibiting only slight or no reduction in HDL cholesterol, thus maintaining up to twofold higher HDL cholesterol levels when fed the atherogenic diet (see Table I). The higher HDL cholesterol levels in mouse apo A-IV transgenic mice may have implications in the relative resistance of these animals to diet- induced aortic lesions (discussed below). In contrast to the atherogenic diet, the Western-type diet typically increases both total and HDL cholesterol, as well as triglycerides $(27,47)$. In the high-expressing human apo A-IV transgenics, the main differences compared with controls were a significant decrease in HDL cholesterol and a large increase in VLDL cholesterol and triglyceride levels, a result of diminished VLDL clearance (27). The low expressor human apo A-IV transgenics exhibited no significant difference from control mice fed the Western-type diet. Based on the available information, it is not possible to determine whether differences between the two transgenic models result from the differences in diet composition or true species-specific differences in apo A-IV.

Of primary interest in the current study is the reduced susceptibility to aortic lesions in the mouse apo A-IV transgenics; aortic lesion susceptibility was not assessed in the human apo A-IV transgenic mice. Lesion scores in transgenics were reduced to $\sim 30 \%$ of those in control mice (Table II). Associated with the reduced lesion scores were twofold higher HDL cholesterol levels and elevated apo A-IV content in HDL of transgenic mice. A potential mechanism by which levels of this protein might influence HDL concentration is through activation of the enzyme LCAT, the key enzyme in the esterification of free cholesterol in plasma lipoproteins. As it has been demonstrated in vitro that apo A-IV is a potent cofactor for this enzyme, increased levels of apo A-IV in the circulation may lead to enhanced LCAT activation and elevated HDL $(17,18)$. Data presented here indicate that plasma from transgenics exhibits a higher cholesterol esterification rate than control mouse plasma, raising the possibility that the elevated apo A-IV levels may lead to increased LCAT activity in plasma of these mice. Consistent with this possibility is the observation that transgenic mice expressing the human LCAT gene exhibit 20$60 \%$ elevations in HDL cholesterol levels, similar to what is observed in the apo A-IV transgenics $(48,49)$. Alternatively, the increased HDL levels in the apo A-IV transgenics could result from altered HDL metabolism in these animals.

The elevated levels of apo A-IV in HDL in transgenic mice also resulted in enhanced cholesterol efflux from loaded human monocyte macrophages. These results support previous observations that apo A-IV-containing lipoproteins take up cellular cholesterol, and thus may participate in the process of "reverse cholesterol transport" $(23,24,50-52)$. It has been shown, for example, that apo A-IV containing liposomes can promote cholesterol efflux from loaded fibroblasts and adipocytes $(23,24)$. Recently, it has been demonstrated that native human plasma lipoproteins derived from apo A-I-deficient patients and containing only apo A-IV protein can serve as initial acceptors of cell-derived cholesterol (52). Furthermore, unlike apo A-I-containing lipoproteins, the apo A-IV-containing particles may catabolize cell-derived cholesterol directly instead of transferring the cholesterol esters to apo B-containing lipoproteins (52).

In addition to ability to promote cholesterol efflux, some properties of HDL that have been related to its antiatherogenicity include protection against oxidative modification of LDL through the action of HDL-associated enzymes such as paraoxonase $(40,41)$. Our studies demonstrate that apo A-IVenriched lipoproteins exhibit greater antioxidant properties as assessed by both direct measurement of paraoxonase activity and by a functional monocyte migration assay. Thus, it is likely that the reduced occurrence of aortic lesions in apo A-IV 
transgenics is associated with both increased HDL levels and altered HDL protein composition, which may in turn influence the metabolism of these lipoproteins and the efficiency with which they promote cellular cholesterol efflux.

Our studies in transgenic mice expressing elevated apo A-IV levels have revealed that this protein may influence HDL levels and reduce aortic lesions. We have further demonstrated that apo A-IV-enriched HDL fractions promote cellular cholesterol efflux with increased efficiency and exhibit antioxidant properties such as increased paraoxonase activity and enhanced ability to protect LDL from oxidative modification. However, none of these properties can be considered unique to apo A-IV, as each have also been ascribed to apo A-I (reviewed in reference 53). It may be that apo A-IV, which is normally present at much lower plasma concentrations than apo A-I, serves a "back-up" function for apo A-I in lipid metabolism. Indeed, it has been demonstrated that a complete lack of apo A-I in knockout mice does not produce increased susceptibility to atherosclerosis (54). It is possible that apo A-IV together with apo E compensate for the lack of apo A-I in this model.

Apo A-IV and apo A-I differ in one respect that may have significant implications for atherosclerosis: the concentration of these two proteins in interstitial fluid. The interstitial fluid is comprised of the microscopic fluid compartment surrounding individual cells and has a total volume that is three to four times that of plasma (reviewed in reference 55). Unlike plasma, the interstitial fluid is in direct contact with peripheral cells, and it is thought that the initial events of cholesterol efflux occur through interaction of interstitial lipoproteins with cell membranes. Studies in dogs have revealed that the ratio of interstitial fluid concentration to plasma concentration of apo A-IV is threefold higher than that for apo A-I; feeding dogs a cholesterol-enriched diet increases the apo A-IV ratio an additional 10-fold (56). Similarly, in rats, the interstitial fluid/plasma concentration ratio for apo A-IV is sevenfold higher than that for apo A-I (57). The increased apo A-IV content of interstitial fluid may be the result of higher rate of capillary filtration of apo A-IV free of lipid or present on small HDL. These observations are consistent with findings in the current study that apo A-IV may have a significant role in reverse cholesterol transport and protection against aortic lesion formation.

It is also interesting to note that under some conditions, apo A-IV expression is modulated independently from apo A-I. For example, in cases of experimentally induced porphyria in mice, hepatic apo A-IV mRNA levels are elevated up to 28fold (58). An even greater increase in hepatic apo A-IV mRNA levels of nearly 100 -fold occurs in neonatal mice carrying the fatty liver dystrophy mutation (59). In both cases apo A-I mRNA levels are normal. These observations may have implications for the specific modulation of apo A-IV expression levels, perhaps for therapeutic alteration of HDL levels.

Note: during revision of this manuscript, it was reported that transgenic mice expressing a human apo A-IV transgene also exhibit reduced aortic lesions (60).

\section{Acknowledgments}

We thank Sarada Charugundla for performing lipid analyses, Hilde Cheroutre for performing oocyte injections, Ping $\mathrm{Xu}$ for assistance with the transgenic mouse colony, Xu-Ping Wang for histological technical assistance, and Tom Leete and Lemenah Tefara for contributions during the early stages of this work.
This work was supported by U.S. Public Health Services Grants HL-28481 (K. Reue, L.W. Castellani, and A.J. Lusis) and HL-30568 (J.-H. Qiao, B.J. Van Lenten, and A.J. Lusis) from the National Institutes of Health. K. Reue is an Established Investigator of the American Heart Association. A.J. Lusis was supported in part by the Laubish Fund, UCLA.

\section{References}

1. Miller, N.E. 1980. HDL cholesterol, tissue cholesterol, and coronary atherosclerosis: epidemiological correlations. In Atherosclerosis. A.M. Gotto, Jr. and B. Allen, editors. Springer Publishing Co., New York. 500-503.

2. Breslow, J.L. 1994. Lipoprotein metabolism and atherosclerosis susceptibility in transgenic mice. Curr. Opin. Lipid. 5:175-184.

3. Paigen, B., A.S. Plump, and E.M. Rubin. 1994. The mouse as a model for human cardiovascular disease and hyperlipidemia. Curr. Opin. Lipid. 5:258-264.

4. Schultz, J.R., and E.M. Rubin. 1994. The properties of HDL in genetically engineered mice. Curr. Opin. Lipid. 5:126-137.

5. Rubin, E.M., R.M. Krauss, E.A. Spangler, J.G. Verstuyft, and S.M. Clift. 1991. Inhibition of early atherogenesis in transgenic mice by human apolipoprotein A-I. Nature (Lond.). 353:265-267.

6. Warden, C.H., C.C. Hedrick, J.-H. Qiao, L.W. Castellani, and A.J. Lusis. 1993. Atherosclerosis in transgenic mice overexpressing apolipoprotein A-II. Science (Wash. DC). 261:469-472.

7. Schultz, J.R., J.G. Verstuyft, E.L. Gong, A.V. Nichols, and E.M. Rubin. 1993. Protein composition determines the anti-atherogenic properties of high density lipoproteins in transgenic mice. Nature (Lond.). 365:761-764.

8. Bisgaier, C.L., O.P. Sachdev, L. Megna, and R.M. Glickman. 1985. Distribution of apolipoprotein A-IV in human plasma. J. Lipid Res. 26:11-25.

9. Vezina, C.A., R.W. Milne, P.K. Weech, and Y.L. Marcel. 1988. Apolipoprotein distribution in human lipoproteins separated by polyacrylamide gradient gel electrophoresis. J. Lipid Res. 29:573-585.

10. Lagrost, L., P. Gambert, M. Boquillon, and C. Lallemant. 1989. Evidence for high density lipoproteins as the major apolipoprotein A-IV-containing fraction in normal human serum. J. Lipid Res. 30:1525-1534.

11. Duverger, N., N. Ghalim, G. Ailhaud, A. Steinmetz, J.-C. Fruchart, and G. Castro. 1993. Characterization of apo A-IV-containing lipoprotein particles isolated from human plasma and interstitial fluid. Arterioscler. Thromb. 13: $126-132$.

12. Weinberg, R.B., and M.S. Spector. 1985. Structural properties and lipid binding of human apolipoprotein A-IV.J. Biol. Chem. 260:4914-4921.

13. Utermann, G., and U. Beisiegel. 1979. Apolipoprotein A-IV: a protein occurring in human mesenteric lymph chylomicrons and free in plasma. Isolation and quantification. Eur. J. Biochem. 99:333-343.

14. Lefevre, M., and P.S. Roheim. 1984. Metabolism of apolipoprotein A-IV. J. Lipid Res. 25:1603-1610.

15. Elshourbagy, N.A., M.S. Boguski, W.S.L. Liao, L.S. Jefferson, J.I. Gordon, and J.M. Taylor. 1985. Expression of rat apolipoprotein A-IV and A-I genes: mRNA induction during development and in response to glucocorticoids and insulin. Proc. Natl. Acad. Sci. USA. 82:8242-8246.

16. Ghiselli, G., S. Krishnan, Y. Beigel, and A.M. Gotto, Jr. 1986. Plasma metabolism of apolipoprotein A-IV in humans. J. Lipid Res. 27:813-827.

17. Steinmetz, A., and G. Utermann. 1985. Activation of lecithin cholesterol acyltransferase by human apolipoprotein A-IV. J. Biol. Chem. 260:22582264.

18. Chen, C.H., and J.J. Albers. 1985. Activation of lecithin cholesterol acyltransferase by human apolipoproteins E-2, E-3, and A-IV. Biochim. Biophys. Acta. 836:279-285.

19. Goldberg, I.J., C.A. Scheraldi, L.K. Yacoub, U. Saxena, and C.L. Bisgaier. 1990. Lipoprotein apo C-II activation of lipoprotein lipase. Modulation by apolipoprotein A-IV. J. Biol. Chem. 265:4266-4272.

20. DeLamatre, J.G., C.A. Hoffmeier, A.G. Lacko, and P.S. Roheim. 1983. Distribution of apolipoprotein A-IV between the lipoprotein and lipoproteinfree fractions of rat plasma: possible role of lecithin:cholesterol acyltransferase. J. Lipid Res. 24:1578-1585.

21. Bisgaier, C.L., O.P. Sachdev, E.S. Lee, K.J. Williams, C.B. Blum, and R.M. Glickman. 1987. Effect of lecithin:cholesterol acyltransferase on distribution of apolipoprotein A-IV among lipoproteins of human plasma. J. Lipid Res. 28:693-703.

22. Weinberg, R.B., J.A. Ibdah, and M.C. Phillips. Adsorption of apolipoprotein A-IV to phospholipid monolayers spread at the air/water interface. A model for its labile binding to high density lipoproteins. J. Biol. Chem. 267: 8977-8983.

23. Stein, O., Y. Stein, M. Lefevre, P.S. Roheim. 1986. The role of apolipoprotein A-IV in reverse cholesterol transport studied with cultured cells and liposomes derived from an ether analog of phosphatidylcholine. Biochim. Biophys. Acta. 878:7-14.

24. Steinmetz, A., R. Barbaras, N. Ghalim, V. Clavey, J.-C. Fruchart, and G. Ailhaud. 1990. Human apolipoprotein A-IV binds to apolipoprotein A-I/AII receptor sites and promotes cholesterol efflux from adipose cells. J. Biol. 
Chem. 265:7859-7863.

25. Fujimoto, K., J.A. Cardelli, and P. Tso. 1992. Increased apolipoprotein A-IV in rat mesenteric lymph after lipid meal acts as a physiological signal for satiation. Am. J. Physiol. 262:G1002-G1006.

26. Fujimoto, K., K. Fukagawa, T. Sakata, and P. Tso. 1993. Suppression of food intake by apolipoprotein A-IV is mediated through the central nervous system in rats. J. Clin. Invest. 91:1830-1833.

27. Aalto-Setälä, K., C.L. Bisgaier, A. Ho, K.A. Kieft, M.G. Traber, H.J. Kayden, R. Ramakrishnan, A. Walsh, A.D. Essenburg, and J.L. Breslow. 1994. Intestinal expression of human apolipoprotein A-IV in transgenic mice fails to influence dietary lipid absorption or feeding behavior. J. Clin. Invest. 93:17761786.

28. Reue, K., D.A. Purcell-Huynh, T.H. Leete, M.H. Doolittle, A. Durstenfeld, and A.J. Lusis. 1993. Genetic variation in mouse apolipoprotein A-IV expression is determined pre-and post-transcriptionally. J. Lipid Res. 34:893-903.

29. Reue, K., and S. Rehnmark. 1994. Screening transgenic mice by PCR: detection of tandem repeats. Biotechniques. 17:252-253.

30. Reue, K., and T.H. Leete. 1991. Genetic variation in mouse apolipoprotein A-IV due to insertion and deletion in a region of tandem repeats. J. Biol. Chem. 266:12715-12721.

31. LeBoeuf, R.C., M.H. Doolittle, A. Montcalm, D.C. Martin, K. Reue, and A.J. Lusis. 1990. Phenotypic characterization of the Ath-1 gene controlling high density lipoprotein levels and susceptibility to atherosclerosis. J. Lipid Res. 31:91-101.

32. Hedrick, C.C., L.W. Castellani, C.H. Warden, D.L. Puppione, and A.J. Lusis. 1993. Influence of mouse apolipoprotein A-II on plasma lipoproteins in transgenic mice. J. Biol. Chem. 268:20676-20682.

33. Jiao, S., T.G. Cole, R.T. Kitchens, B. Pfleger, and G. Schonfeld. 1990. Genetic heterogeneity of plasma lipoproteins in the mouse: control of low density lipoprotein particle sizes by genetic factors. J. Lipid Res. 31:467-477.

34. Qiao, J.H., P.Z. Xie, M.C. Fishbein, J. Kreuzer, T.A. Drake, L.L. Demer, and A.J. Lusis. 1994. Pathology of atheromatous lesions in inbred and genetically engineered mice. Genetic determination of arterial calcification. Arterioscler. Thromb. 14:1480-1497.

35. Bernard, D.W., A. Rodriguez, G.H. Rothblatt, and J.M. Glick. 1990. Influence of high density lipoprotein on esterified cholesterol stores in macrophages and hepatoma cells. Arteriosclerosis. 10:135-144.

36. Navab, M., G.P. Hough, L.W. Stevenson, D.C. Drinkwater, H. Laks, and A.M. Fogelman. 1988. Monocyte migration into the subendothelial space of a coculture of adult human aortic endothelial and smooth muscle cells. $J$. Clin. Invest. 82:1853-1863.

37. Van Lenten, B.J., S.Y. Hama, F.C. de Beer, D.M. Stafforini, T.M. McIntyre, S.M. Prescott, B.N. La Du, A.M. Fogelman, and M. Navab. 1995. Antiinflammatory HDL becomes pro-inflammatory during the acute phase response. Loss of protective effect of HDL against LDL oxidation in aortic wall co-cultures. J. Clin. Invest. 96:2758-2767.

38. Ohta, T., R. Nakamura, K. Takata, Y. Saito, S. Yamashita, S. Horiuchi, and I. Matsuda. 1995. Structural and functional differences of subspecies of apoAI-containing lipoprotein in patients with plasma cholesteryl ester transfer protein deficiency. J. Lipid Res. 36:696-704.

39. Walsh, A., N. Azrolan, K. Wang, A. Marcigliano, A. O'Connell, and J.L. Breslow. 1993. Intestinal expression of the human apo A-I gene in transgenic mice is controlled by a DNA region $3^{\prime}$ to the gene in the promoter of the adjacent convergently transcribed apo C-III gene. J. Lipid Res. 34:617-623.

40. Berliner, J.A., M. Navab, A.M. Fogelman, J.S. Frank, L.L. Demer, P.A. Edwards, A.D. Watson, and A.J. Lusis. 1995. Atherosclerosis: basic mechanisms. Oxidation, inflammation, and genetics. Circulation. 91:2488-2496.

41. Mackness, M.I., S. Arrol, and P.N. Durrington. 1991. Paraoxonase prevents accumulation of lipoperoxides in low density lipoprotein. FEBS Lett. 286: $152-154$.

42. Watson, A.D., M. Navab, S.Y. Hama, A. Sevanian, S.M. Prescott, D.M. Stafforini, T.M. McIntyre, B.N. La Du, A.M. Fogelman, and J.A. Berliner. 1995. Effect of platelet activating factor-acetylhydrolase on the production and activity of mildly oxidized low density lipoprotein. J. Clin. Invest. 95:774-782.

43. Fielding, C.J., and P.E. Fielding. 1981. Evidence for a lipoprotein carrier in human plasma catalyzing sterol efflux from cultured fibroblasts and its relationship to lecithin: cholesterol acyltransferase. Proc. Natl. Acad. Sci. USA. 78: 3911-3914.

44. Schultz, J.R., J.G. Verstuyft, E.L. Gong, A.V. Nichols, and E.M. Rubin 1992. Expression of human apolipoprotein A-II and its effect on high density lipoproteins in transgenic mice. J. Biol. Chem. 267:21630-21636.

45. Bisaha, J.G., T.C. Simon, J.I. Gordon, and J.L. Breslow. 1995. Characterization of an enhancer element in the human apolipoprotein C-III gene that regulates human apolipoprotein A-I gene expression in the intestinal epithelium. J. Biol. Chem. 270:19979-19988.

46. Ishida, B.Y., P.J. Blanche, A.V. Nichols, M. Yashar, and B. Paigen. 1991. Effects of atherogenic diet consumption of lipoproteins in mouse strains C57BL/6 and C3H. J. Lipid Res. 32:559-568.

47. Plump, A.S., J.D. Smith, T. Hayek, K. Aalto-Setala, A. Walsh, J.G. Verstuyft, E.M. Rubin, and J.L. Breslow. 1992. Severe hypercholesterolemia and atherosclerosis in apolipoprotein E-deficient mice created by homologous recombination in ES cells. Cell. 71:343-353.

48. Mehlum, A., B. Staels, N. Duverger, A. Tailleux, G. Castro, C. Fievet, G. Luc, J.-C. Fruchart, G. Olivecrona, G. Skretting, et al. 1995. Tissue-specific expression of the human gene for lecithin:cholesterol acyltransferase in transgenic mice alters blood lipids, lipoproteins and lipases toward a less atherogenic profile. Eur. J. Biochem. 230:567-575.

49. Francone, O.L., E.L. Gong, D.S. Ng, C.J. Fielding, and E.M. Rubin. 1995. Expression of human lecithin-cholesterol acyltransferase in transgenic mice. Effect of human apolipoprotein A-I and human apolipoprotein A-II on plasma lipoprotein cholesterol metabolism. J. Clin. Invest. 96:1440-1448.

50. Weinberg, R.B., and C.S. Patton. 1990. Binding of human apolipoprotein A-IV to human hepatocellular plasma membranes. Biochim. Biophys. Acta. 1044:255-261.

51. Duverger, N., N. Ghalim, G. Ailhaud, A. Steinmetz, J.-C. Fruchart, and G. Castro. 1993. Characterization of apo A-IV-containing lipoprotein particles isolated from human plasma and interstitial fluid. Arterioscler. Thromb. 13: $126-132$.

52. von Eckardstein, A., Y. Huang, S. Wu, A.S. Sarmadi, S. Schwarz, A. Steinmetz, and G. Assmann. 1995. Lipoproteins containing apolipoprotein A-IV but not apolipoprotein A-I take up and esterify cell-derived cholesterol in plasma. Arterioscler. Thromb. 15:1755-1763.

53. Stampfer, M.J., F.M. Sacks, S. Salvini, W.C. Willett, and C.H. Hennekens. 1991. A prospective study of cholesterol, apolipoproteins, and the risk of myocardial infarction. N. Engl. J. Med. 325:373-381.

54. Li, H., R.L.Reddick, and N. Maeda. 1993. Lack of apo A-I is not associated with increased susceptibility to atherosclerosis in mice. Arterioscler. Thromb. 13:1814-1821.

55. Sloop, C.H., L. Dory, and P.S. Roheim. 1987. Interstitial fluid lipoproteins. J. Lipid Res. 28:225-237.

56. Sloop, C.H., L. Dory, R. Hamilton, B.R. Krause, and P.S. Roheim. 1983. Characterization of dog peripheral lymph lipoproteins: the presence of a discshaped "nascent" high density lipoprotein. J. Lipid Res. 24:1429-1440.

57. Roheim, P.S., D. Edelstein, and G.G. Pinter. 1976. Apolipoproteins in rat serum and renal lymph. Proc. Natl. Acad. Sci. USA. 73:1757-1760.

58. Buchberg, A.M., and A.J. Kinniburgh. 1985. Induction of liver apolipoprotein A-IV mRNA in porphyric mice. Nucleic Acids Res. 13:1953-1963.

59. Langner, C.A., E.H. Birkenmeier, O. Ben-Zeev, M.C. Schotz, H.O Sweet, M.T. Davisson, and J.I. Gordon. 1989. The fatty liver dystrophy (fld) mutation. A new mutant mouse with a developmental abnormality in triglyceride metabolism and associated tissue-specific defects in lipoprotein lipase and hepatic lipase activities. J. Biol. Chem. 264:7994-8003.

60. Duverger, N., G. Tremp, J.-M. Caillaud, F. Emmanuel, G. Castro, J.-C. Fruchart, A. Steinmetz, and P. Denéfle. 1996. Protection against atherogenesis in mice mediated by human apolipoprotein A-IV. Science (Wash. DC.). 273: 966-968. 